\title{
Influence of teaching style and achievement motivation towards the results of learning services to volleyball
}

\author{
Felinda Sari ${ }^{1}$, Agus Kristiyanto ${ }^{2}$, Tri Aprilijanto Utomo ${ }^{3}$ \\ ${ }^{123}$ Sebelas Maret University
}

DOI: https://doi.org/10.34142/HSR.2020.06.02.06

\begin{abstract}
The aim of this study was to determine the difference in influence between command teaching style and inclusive teaching style on the results of service learning.

Material and methods. This research is an experimental research with a $2 \times 2$ factorial design. This research was conducted in Sukoharjo State Junior High School, Pringsewu Regency, Lampung Province.The implementation of the treatment of the volleyball service with Command Style and Inclusion Style teaching in Extracurricular students of Sukoharjo State Junior High School, Pringsewu Regency, Lampung Province. This research is an experimental study that aims to compare two different treatments to research subjects using factorial design techniques meaning that there are two factors studied. The research design used is the treatment design by level $2 \times 2$.

Results. Based on the results of the research and the results of data analysis that have been done, the following conclusions can be obtained: 1) There is a significant difference in influence between the Komando teaching style and the teaching style of inclusion in improving service results on volleyball $(p<0.05)$. The effect of the command teaching style method is better than the inclusion teaching style in improving the service outcome of volleyball. 2) There is a significant difference in the results of service for volleyball between students who have high and low achievement motivation $(p<0.05)$.

Conclusion. The results of service on volleyball in students who have high achievement motivation are better than those who have low achievement motivation. 3) There is no significant interaction effect between teaching style and achievement motivation on the results of service on volleyball ( $p>0.05)$.
\end{abstract}

Keywords: Teaching Style; Motivation; Volleyball

\section{Анотація}

Фелінда Сарі, Аргус Кристіано, Три Априліанто Утомо. Вплив стилю навчання та мотивації досягнень на результати навчання волейболу

Мета цього дослідження полягала в тому, щоб визначити різницю між впливом стилю командного навчання і стилю інклюзивного навчання на результати навчання

Матеріал і методи. Це дослідження є експериментальним з факторіальним дизайном 2х2. Дане дослідження було проведено в середній школі штату Сукохарджо, Регінсе Прінгсеву, провінція Лампунг. Було проведено навчання юних волейболістів 3 викладанням командного стилю та інклюзивного стилю. Це дослідження є експериментальним, метою якого $€$ порівняння двох різних методів навчання з використанням методів факторного проектування. Використовуваний дизайн дослідження - це план навчання за рівнем $2 \times 2$.

Результати. Було виявлено: 1) Існує достовірна різниця у впливі команднимого стилю навчання та інклюзивного стилю навчання на результати технріческоого майстерності юних волейболістів ( $<<0,05)$. Ефект методу командного стилю викладання кращий, ніж інклюзивного стилю викладання з точки зору впливу на технічну майстерність юних волейболістів. 2) Існує значна різниця в результатах навчання техніці волейболу між учнями, які мають високу і низьку мотивацію досягнення $(p<0,05)$.

Висновки. Результати навчання техніці волейболу студентів з високою мотивацією досягнення краще, ніж у тих, у кого низька мотивація досягнення. Не існує значного впливу взаємодії між стилем навчання і мотивацією досягнень на результати технічної майстерності у волейболі ( $>>0,05)$.

Ключові слова: стиль викладання; мотивація; волейбол

\section{Аннотация}

Фелинда Сари, Аргус Кристиано, Три Апрлианто Утомо. Влияние стиля преподавания и мотивации достижения на результаты обучения волейболу.

Цель этого исследования состояла в том, чтобы определить разницу между влиянием стиля командного обучения и стиля инклюзивного обучения на результаты обучения

Материал и методы. Это исследование является экспериментальным с факториальным дизайном 2х2. Данное исследование было проведено в средней школе штата Сукохарджо, Регинсе Прингсеву, провинция Лампунг. Было проведено обучение юных волейболистов с преподаванием командного стиля и инклюзивного стиля. Это исследование является экспериментальным, целью которого является сравнение двух разных методов обучения с использованием методов факторного проектирования. Используемый дизайн исследования - это план обучения по уровню 2 × 2.

Результаты. Было выявлено: 1) Существует достоверная разница во влиянии команднымого стиля обучения и инклюзивного стиля обучения на результаты технрическоого мастерства юных волейболистов $(p<0,05)$. Эффект метода командного стиля преподавания лучше, чем инклюзивного стиля преподавания с точки зрения влияния на техническое мастерство юных волейболистов. 2) Существует значительная разница в результатах обучения технике волейбола между учащимися, которые имеют высокую и низкую мотивацию достижения $(p<0,05)$.

Выводы. Результаты обучения технике волейбола студентов с высокой мотивацией достижения лучше, чем у тех, у кого низкая мотивация достижения. Не существует значительного влияния взаимодействия между стилем обучения и мотивацией достижений на результаты технического мастерства в волейболе $(p>0,05)$.

Ключевые слова: стиль преподавания; мотивация; волейбол 


\section{Introduction}

Volleyball is a big ball team game [1]. Volleyball game is played by two teams or teams, each team consists of 6 players. This game requires coordination and teamwork. Volleyball game was created by William G. Morgan in 1895. Initially the name of the game was called "Minonette" which is almost similar to the game of badminton. Then the name of the game was changed to "Volley-Ball" which means more or less memvolley ball alternately [2]. In Indonesia began to recognize this game since 1928, namely through soldiers from the Netherlands. Then soon, there were various volleyball clubs in Indonesia. Initially on January 22, 1955, in Jakarta stood PBVSI (All Indonesia Volleyball Association), namely as the main volleyball in Indonesia [3].

Volleyball service is an action or sign taken to start or start a volleyball game [4]. There are also other opinions that suggest that volleyball service is a soccer ball which is carried out by players from behind the finish line of the playing field by going over the net to the opponent's playing field [5]. Service in a volleyball boal game can be done in 2 kinds of ways, namely by servicing the top and bottom servicing [6]. First, volleyball under-service is a service that is done by swinging the arm from under the back or front, then swinging the ball with the palm of your hand [7]. While the second, service for volleyball is a service that is done by hitting the ball that is thrown over the front of the head. To do this service requires more power or power so that the service ball can go fast (shot at high speed) so that the service ball will be difficult to accept the opponent can even turn off the opposing team. Initially the service was only intended as a service or just a sign to start the match, but along with the development of volleyball now the service can also be used as an initial attack to get a point or point so that the team gets a victory [8]. Top service is one of the services that is very relied upon by volleyball players due to the difficulty of sending the ball to the opponent when serving up. But top service is one of the most difficult volleyball services, especially for beginners. For beginners learning sports especially volleyball is usually done during class hours of sports or take part in volleyball extracurricular activities in their schools [9].

The problem faced by teachers in general is what method is right to be applied to students. To improve students' movement skills, teaching methods or styles that are appropriate to the conditions of the students are needed [10]. There are several forms of teaching styles that can be used to improve volleyball playing skills. Teaching styles that can be used to train basic techniques, especially service on volleyball, include command teaching style and inclusive teaching style [11].

From the overall teaching style above and based on the background of the problem and the boundary of the problem, in this study two teaching styles were chosen as research material, namely the command style and the inclusion teaching style.

1) Command Teaching Style

Command style is the teaching approach that is most dependent on the teacher [12]. The teacher prepares all aspects of teaching [13]. The teacher is fully responsible and initiative towards teaching and monitoring learning progress [14]. The purpose of the command style is for students to carry out tasks carefully and in a relatively short period of time while all decisions come from the teacher [15]. Command style (the command style), is the teaching approach that is most dependent on the teacher, the teacher prepares all aspects of teaching, the teacher is fully responsible and takes the initiative of teaching and monitors learning progress [16].

Typically, the style begins with an explanation of standard techniques and then the students copy and do it repeatedly. While the evaluation is based on the goals that have been set, students are guided to the same goal as all [17].

The characteristics of the command style are:

a) All decisions are taken by the teacher in each episode of learning.

b) Targets and targets are achieved by relying on student compliance, including: uniformity of appearance, matching performance, and imitating the examples provided.

c) Order of activities: demonstration, explanation, implementation, and assessment.

d) his style will result in a high level of activity and evaporation of discipline, due to the imposition of command or coercive orders.

Each style in a spectrum affects the learning process in students, fields of study and ways of assignment. The implications of using command style in learning activities are:

a) Standards of appearance that have been established

b) Learning material is learned by imitating

c) Learning material is divided up so that it is easy to imitate

d) There are no individual differences.

In addition to the command teaching style, there are also several other teaching styles, one of which is the inclusion teaching style. The teaching style of inclusion is a teaching style that presents the learning material as a whole in detail the level of difficulty [18], then students are given the freedom to choose and determine at which level the student starts learning, and given the freedom to determine the 
number of times students must repeat the movement in learning a technique movements in each meeting. So with this inclusive teaching style athletes are given the freedom to be creative and determine the level of difficulty according to their abilities. The reality in the field of inclusive teaching style is still rarely used for a variety of reasons [19].

2) The Inclusion Style

Inclusive teaching style is a teaching style that presents the overall learning material in detail described the level of difficulty [20]. Students are given the freedom to choose and determine at what level of difficulty students begin to learn, and are also given the freedom to determine the number of times students must repeat the movement in learning a movement technique in each meeting. The teaching style of inclusion introduces various levels of assignment. While the command teaching style, training, reciprocity, self-examination show a single standard of performance, while the inclusion style assigns tasks that vary in their level. In the teaching style of inclusion students are encouraged to determine their level of performance. The purpose of inclusive teaching style, namely: a) Involve all students b) Adjustments to individual differences c) Give an opportunity to start at the level of ability alone. d) Give the opportunity to start working with light or heavy tasks, according to the level of student ability. e) Learn to see the relationship between abilities and tasks that students can do. f) Individualism is possible because of choosing between alternative levels of task that has been provided.

\section{Methods}

This research is planned to be carried out at Sukoharo 1 Public Middle School, Pringsewu Lampung. For the implementation of the treatment of the volleyball service with Command Style and Inclusion Style teaching in Extracurricular students of SMP Negeri 1 Sukoharjo, Pringsewu Lampung.

This research is an experimental study that aims to compare two different treatments to research subjects using factorial design techniques meaning that there are two factors studied. Factorial experiments are experiments that almost or all levels of a factor are combined or crossed with all levels of each other factors that exist in the experiment. The first factor is the teaching style consisting of Command Style and Inclusion Style, the second factor is the student achievement motivation which consists of high achievement motivation level and low achievement motivation level.

The research design used is the treatment design by level $2 \times 2$. The treatment design by level, is an action on one or more variables that are manipulated simultaneously to be able to study the effect of each variable on the dependent variable or the effect caused by the interaction between several variables. Factorial designs are experimental units into cells in such a random way. The data in this study compiled a research design framework with treatment design by level $2 \times 2$ :

Factorial Design $2 \times 2$

\begin{tabular}{lcc}
\hline & \multicolumn{2}{c}{ Teaching Style (A) } \\
\cline { 2 - 3 } Student Achievement Motivation (B) & Command Style (A1) & The Inclusion Style (A2) \\
\hline Height (B1) & A1 B1 & A2 B1 \\
\hline Low (B1) & A1 B2 & A2 B2 \\
\hline
\end{tabular}

Notes:

A1 B1: is the presentation of service material on volleyball with command style given to groups that have a high level of achievement motivation.

A1 B2: is the presentation of service material on volleyball with the command style given to groups that have low levels of achievement motivation.

A2 B1: is the presentation of service material for volleyball with the inclusion style given to groups that have a high level of achievement motivation high.

A2 B2: is the presentation of service material on volleyball with the inclusion style given to groups that have a low level of achievement motivation.

In this study the samples to be examined were 40 students who took volleyball extracurricular activities at Sukoharjo State Junior High School, Pringsewu Regency, Lampung Province. The sampling technique used was purposive random 
sampling. Data collection techniques used in this study were tests and measurements. The data analysis technique used is the two lane variance (anava) technique at $=5 \%$. If the $\mathrm{F}$ value obtained $(\mathrm{Fo})$ significant analysis continued with hewman-keuls test. To fulfill assumptions in the anava technique. Then do the normality test (lilliefors test) and Homogeneity Variance test (with Bartlerr test).

\section{Results}

1. Normality Test

Before analyzing the data it is necessary to test the normal distribution. The data normality test in this study uses the SPSS 22 Normality Test. The results of the data normality test conducted in each group are as follows:

Table 2

Summary of Data Normality Test Results

\begin{tabular}{lcclll}
\hline Treatment Group & $\mathrm{N}$ & $\begin{array}{c}\text { Significance } \\
\text { Value }\end{array}$ & & Norm & Conclusion \\
\hline A1B1 & 10 & 0,410 & $>$ & 0,05 & $\begin{array}{l}\text { Normal } \\
\text { distribution }\end{array}$ \\
\hline A1B2 & 10 & 0,527 & $>0,05$ & $\begin{array}{l}\text { Normal } \\
\text { distribution }\end{array}$ \\
\hline A2B1 & 10 & 0,937 & $>0,05$ & $\begin{array}{l}\text { Normal } \\
\text { distribution }\end{array}$ \\
\hline A2B2 & 10 & 0,124 & $>0,05$ & $\begin{array}{l}\text { Normal } \\
\text { distribution }\end{array}$ \\
\hline
\end{tabular}

From the results of the normality test conducted on a1b1 the value of $\operatorname{sig}=0.410$ if the value is greater than the rejection limit value at the $5 \%$ significance level of 0.05 . Thus it can be concluded that the data in alb1 are normally distributed. From the results of the normality test conducted on a1b2 obtained sig $=0.527$, which turned out to be greater than the null hypothesis rejection limit value using a 5\% significance of 0.05 . Thus, it can be concluded that the data in A1b2 is normally distributed. From the results of the normality test conducted on a2b1, the Sig $=0.937$ was obtained. This value is greater than the rejection limit using a 5\% significance of 0.05 . Thus it can be concluded that the data in a2b1 is normally distributed. The results of the normality test conducted on a2b2 obtained Sig $=0.124$, which was also smaller than the null rejection limit number using a 5\% significance of 0.05 . Thus it can be concluded that the data on a $2 \mathrm{~b} 2$ also includes normal distribution.

\section{Homogeneity Test}

Homogeneity test is intended to test the similarity of variance between group 1 and group 2 . The homogeneity test in this study was carried out by the Levenes SPSS 22 test. The results of the data homogeneity test between group 1 and group 2 are as follows:

Table 3

Summary of Data Homogeneity Test Results

\begin{tabular}{cccccc}
\hline$\sum$ Group & $\mathrm{Ni}$ & Score Sig & & Norm Sig & Conclusion \\
\hline 4 & 40 & 0,433 & $>$ & 0,05 & $\begin{array}{c}\text { Varians } \\
\text { homogeny }\end{array}$ \\
\hline
\end{tabular}

If the Significance value is greater than 0.05 then the data is declared homogeneous but if on the contrary the significance value is less than 0.05 then the data is declared not homogeneous from the homogeneity test results obtained Sig $=0.433$ greater than 0.05 then the data is declared homogeneous.

\section{Hypothesis Testing}

Research hypothesis testing is based on the results of data analysis and analysis of variance interpretation using the SPSS 22 test, there are several hypotheses that must be tested. The testing sequence is adjusted to the order of the hypotheses formulated in Chapter II. The results of data analysis, which are needed for hypothesis testing are as follows: 
Table 4

Summary of Average Service Values of Volleyball Based on the Use of Teaching Style and Achievement Motivation Levels.

\begin{tabular}{lcccc}
\hline \multicolumn{1}{c}{ Variable } & & A1 & & A2 \\
\hline $\begin{array}{l}\text { Average Service Results } \\
\text { Top Volleyball }\end{array}$ & B1 & B2 & B1 & B2 \\
\cline { 2 - 4 } & & & & \\
\hline Preliminary test results & 13,7 & 12,9 & 12,8 & 11,6 \\
\hline Final test results & 20,9 & 16,8 & 18,7 & 14,6 \\
\hline Enhancement & 7,2 & 3,9 & 5,9 & 3 \\
\hline
\end{tabular}

Tests of Between-Subjects Effects Results

\begin{tabular}{|c|c|c|c|c|c|}
\hline Source & Sum of Square & Df & $\begin{array}{l}\text { Mean } \\
\text { Square }\end{array}$ & $\mathrm{F}$ & Sig \\
\hline Corrected Model & $216.500 a$ & 3 & 72.167 & 25.223 & .000 \\
\hline Intercept & 12602.500 & 1 & 12602.500 & $4.405 \mathrm{E} 3$ & .000 \\
\hline Teaching style & 48.400 & 1 & 48.400 & 16.917 & .000 \\
\hline Motivation & 168.100 & 1 & 168.100 & 58.753 & .000 \\
\hline $\begin{array}{l}\text { Teaching Style * } \\
\text { Motivation }\end{array}$ & .000 & 1 & .000 & .000 & 1.000 \\
\hline Error & 103.000 & 36 & & & \\
\hline Total & 12922.000 & 40 & & & \\
\hline
\end{tabular}

Table 5

Table 6

Data Description of Service Test Results for Volleyball by Each Group Based on the Use of Teaching Style and Achievement Motivation Levels

\begin{tabular}{|c|c|c|c|c|c|}
\hline Treatment & $\begin{array}{c}\text { Level of } \\
\text { Motivation }\end{array}$ & Statistics & $\begin{array}{c}\text { Test Results } \\
\text { Early }\end{array}$ & $\begin{array}{c}\text { Test Results } \\
\text { End }\end{array}$ & Enhancement \\
\hline \multirow{6}{*}{$\begin{array}{l}\text { Teaching Style } \\
\text { Command }\end{array}$} & & Amount & 209 & 137 & 72 \\
\hline & \multirow[b]{2}{*}{ High } & Average & 20,9 & 13,7 & 7,2 \\
\hline & & SD & 1,37032 & 2,110819 & 2,616189 \\
\hline & \multirow{3}{*}{ Low } & Amount & 129 & 168 & 39 \\
\hline & & Average & 12,9 & 16,8 & 3,9 \\
\hline & & SD & 1,66333 & 1,873796 & 2,643651 \\
\hline \multirow{6}{*}{$\begin{array}{l}\text { Teaching Style } \\
\text { Inclusion }\end{array}$} & \multirow{3}{*}{ High } & Amount & 128 & 187 & 59 \\
\hline & & Average & 12,8 & 18,7 & 5,9 \\
\hline & & SD & 1,135292 & 2,162817 & 2,84605 \\
\hline & \multirow{3}{*}{ Low } & Amount & 116 & 146 & 30 \\
\hline & & Average & 11,6 & 14,6 & 3 \\
\hline & & SD & 0,966092 & 1,173788 & 2 \\
\hline
\end{tabular}




\section{Discussion}

Based on the results of the above data analysis, the following hypotheses can be tested:

1) First Hypothesis Testing

From the results of the study showed that the command teaching style had an increase that was different from the inclusive teaching style [10-13]. This is evidenced from the value of Sig $=0.00<0.05$. Thus the null hypothesis (H0) is rejected. Which means that the command teaching style has an increase that is different from the inclusive teaching style [14-16]. From the follow-up analysis it was found that the command teaching style had a better improvement than the inclusive teaching style, with an average increase of 18.85 and 16.65 , respectively.

\section{2) Second Hypothesis Testing}

From the results of the study showed that students who have high achievement motivation have increased service results on volleyball that are different from students who have low achievement motivation [17-20]. This is evidenced from the value of $\mathrm{Sig}=0.00<0.05$ Thus the null hypothesis $(\mathrm{H} 0)$ is rejected. Which means that students who have high achievement motivation have improved service results on volleyball that are different from students who have low achievement motivation that can be accepted as correct. From the follow-up analysis it was found that students who had High Achievement Motivation had improved volleyball service results better than students who had Low Achievement Motivation, with an average increase of 19.8 and 15.7 respectively.

3) Third Hypothesis Testing

The results of the study showed that the interaction between differences in teaching styles and levels of student achievement motivation was not significant. Because Sig $=1.00>0.05$. Thus hypothesis one is rejected and the null hypothesis is accepted, meaning there is no interaction between teaching style and achievement motivation on the results of service on student volleyball.

\section{Conclusion}

Based on the results of research and the results of data analysis that has been done, the following conclusions can be obtained:

1. There is a significant difference in influence between Komando's teaching style and the inclusive teaching style in improving the service outcome of volleyball $(p<0.05)$. The effect of the command teaching style method is better than the inclusion teaching style in improving the service outcome of volleyball.

2. There is a significant difference in the results of service for volleyball between students who have high and low achievement motivation $(\mathrm{p}<0.05)$. The results of service on volleyball in students who have high achievement motivation are better than those who have low achievement motivation.

3. There is no significant interaction effect between teaching style and achievement motivation on the results of service on volleyball ( $p>0.05)$.

\section{Conflict of interest}

The authors report that there is no conflict of interest.

Hasil Belajar Mahasiswa Pada Mata Kuliah Teori Praktek Bola Voli. J Penelit Pendidik. 2010;27(2).

7. Keolahragaan J. Pengaruh Metode Latihan dan Koordinasi Mata-Tangan terhadap Keterampilan Servis Atas Bola Voli. 2017;5(1):100-10.

8. Jenny Indra Sabilla dan MJ. Intimasi PelatihAtlet dan Kecemasan Bertanding Pada Atlet Bola Voli Putri Jenny Indra Sabilla, dan Miftakhul Jannah Program Studi Psikologi Universitas Negeri Surabaya. J Psikol Teor dan Terap. 2017;7(2):123-9.

9. Putro DE, Lumintuarsa R. Pengembangan Media Pembelajaran Teknik Dasar Bola Voli ... Danang Endarto Putro, Ria Lumintuarsa 37. 1(1):37-48.

10. Septiyanto A. Ketepatan floating service atlet bola voli the effect of imagery training method and concentration. :412-20.

11. Suko T, Wiyono B. Motivation, learning strategy , and learning achievement of the students at depok 2 state vocational school ( smk negeri 2 depok) Sleman. 2008;

12. Permana H. Pengaruh Sirkuit Training Awal 
Akhir Latihan Teknik ... Hendri Permana, Suharjana 49. 2013;1:49-62.

13. Dutra LN, Benda RN, Lage GM, Ugrinowitsch H. Difficult group goal improves serve reception of experienced volleyball players. 12(2):276-85.

14. Pradina Y., Pramono M. Tingkat Kecemasan Atlet Bolavoli Putri Pada Kejuaraan Liga Remaja Tingkat Jawa Timur Tahun 2016. J Kesehat Olahraga. 2016;

15. Rahmat D, Wahidi R. Pengaruh Pembelajaran Passing Berpasangan Terhadap Keterampilan Passing Bawah Dalam Permainan Bola Voli. JUARA J Olahraga. 2018;

16. Pasaribu AMN. Pengaruh Gaya Mengajar dan Motivasi Belajar Passing Bawah Dalam Permainan Bola Voli Pada Siswa SMP Kelas VIII Tahun 2013/2014. J
Sport J Penelit Pembelajaran. 2016;2(2):85.

17. Candra A, Henjilito R. Pengaruh Latihan Pukulan Menggunakan Imagery Terhadap Hasil Smash Permainan Bolavoli. J Sport Area. 2018;3(2):102-10.

18. Marwati M. Upaya meningkatkan keterampilan servis atas permainan bola voli tahun pelajaran 20142015. Briliant J Ris dan Konseptual. 2016;

19. Astuti Y. Pengaruh Metode Drill dan Metode Bermain Terhadap Keterampilan Bermain Bola Voli Mini (Studi Eksperimen Pada Siswa SD Negeri 14 Kampung Jambak Kecamatan Koto Tangah Kota Padang). Al Ibtida J Pendidik Guru MI. 2017;

20. Hanafi S. Hubunganmotor fitnessdenganketerampilan bermainbola voli Fazlullah. J Il. 2015;

\section{Information about the authors}

\section{Felinda Sari}

felindasari@student.uns.ac.id

http://orcid.org/0000-0003-0106-4674

Sebelas Maret University

Street Ir. Sutami Number 36 Surakarta City, Central Java, Indonesia

\section{Agus Kristiyanto}

aguskriss@yahoo.co.id

http://orcid.org/0000-0001-7961-4643

Sebelas Maret University

Street Ir. Sutami Number 36 Surakarta City, Central Java, Indonesia

\section{Tri Aprilijanto Utomo}

aprili_janto@yahoo.com ${ }^{3}$

http://orcid.org/0000-0003-4043-9766

Sebelas Maret University

Street Ir. Sutami Number 36 Surakarta City, Central Java, Indonesia

\section{Інформація про авторів}

\section{Фелінда Сарі}

felindasari@ student.uns.ac.id

0000-0003-0106-4674

Університет одинадцятого березня

вул. Ір. Сутамі, 36, м. Сураката, Центральна Ява, Індонезія

\section{Аргус Кристіано}

aguskriss@yahoo.co.id

0000-0001-7961-4643

Університет одинадцятого березня

вул. Ір. Сутамі, 36, м. Сураката, Центральна Ява, Індонезія

\section{Три Априліанто Утомо}

aprili_janto@yahoo.com

0000-0003-4043-9766

Університет одинадцятого березня

вул. Ір. Сутамі, 36, м. Сураката, Центральна Ява, Індонезія 